\title{
Dynamics of government decision-making process on the policy level towards Thai State owned enterprises (SOEs)
}

\author{
Sutada Mekrungruengkul \\ Faculty of Public Administration, National Institute of Development Administration, Thailand. \\ E-mail:mod.sutada@gmail.com.
}

Accepted 15 December, 2010

\begin{abstract}
This research study on the government decision-making process on the policy level towards Thai State owned enterprises (SOE) offers some ideas that may provide a useful interpretation of the government decision-making process on the policy level of public administration. The researcher aims to propose a better understanding of government policy formulation and implementation towards Thai SOE through two case studies. The findings of the study support the analytical framework that in the stage of agenda setting, the garbage-can model is the decision-making model that helps explain the processes of agenda setting, due to the variety of participants that influence the decision-making processes. However, the incremental model is more explanatory in the following stage. Once the policy is decided and implemented, policies are formulated and the day-to-day operational decisions are made incrementally by the ministry's high-ranking officials and the SOE management. Moreover, the researcher found that government policies towards these two SOEs were, very often, on and off, and the government took about three to four decades with several governments to push the policies to be implemented and accomplished.
\end{abstract}

Key words: Organizational decision-making process, State owned enterprises (SOEs), satisfying model, incremental model, garbage-can model, the garbage-can model in political institutions as according to Kingdon's theory, Thai administrative culture, the politics of despotic paternalism.

\section{A BRIEF PREVIEW OF THE ARTICLE}

The aim of this study is to understand the dynamics of government decision-making process on the policy level towards Thai State owned enterprises (SOEs) by focusing on examining the factors that have major roles in influencing the decision-making process. It considers why some government policy implementations in a particular issue are inconsistent, changeable and uncontinuous, and in some periods of time there is no action taken towards those policies and why the decision makers changed their mind to the new alternatives after they have already made a decision.

This article comprises: (1) Organizational decisionmaking models; (2) Conceptual framework for analysis and research methodology; (3) Case studies; (4) The analysis which includes: Participant factors (Explanation of the political structures and institutions surrounding the government decision-making process on the policy level towards state owned enterprises), process factors
(Explanation of the political structures and institutions surrounding the government decision-making process on the policy level towards state owned enterprises), governmental decision making, window of opportunities and coupling the models' streams of government decision-making process on the policy level towards Thai State owned enterprises; (5) Conclusion; and (6) the developing research "The dynamics of government decision-making process on the policy level towards Thai State owned enterprises (SOEs) operating within metropolitan areas".

\section{ORGANIZATIONAL DECISION-MAKING MODELS}

This study tries to understand what kind of decisionmaking process, decision makers use in making decisions on the policy level towards SOEs in which the researcher focuses and uses the models as a tool for 
analysis. These organizational decision-making models include the Instrumental Rationallity Model proposed by Max Weberi (March et al., 1993). The characteristics of this model consists of 4 steps. Firstly, the definition of the goals that were rather clearly set in advance and the levels of achievement of those goals that were set. This can be explained with the agenda setting process, which might not be carried on by those who make the decision, and this is the weakness of this model. Secondly, the many alternatives that might achieve these goals can be canvassed. Thirdly, the alternatives would be systematically compared along with the assessment of the costs and benefits. Finally, the decision makers would choose the alternatives that would achieve their goals at the least cost. The 'satisfying model', proposed by Herbert A. Simon in which he begins his argument by proposing the model of "administrative man" as an alternative to "economic man", is used to provide some materials for the construction of a theory of the behavior of human individuals or of groups of individuals who are making decisions in an organizational context (Simon, 1955: 99-118). He points out that the administrative management of an individual organization is different from the economic system and cannot be used to explain human decision-making processes. One can conclude that "economic man" differs from "rational man" as it is always claimed by economists that "ceteris paribus" - this thing will be like that thing. A major implication of Simon's decision-making conceptualization is the recognition that the rational actor may not be able to pick up the best possible alternative because of the uncertainties in predicting the future state of affairs. Thus, this model emphasizes the limitation of administrative rationality existing in the organizational context (Michael and Richard, 1986: 147). For the fact that the rationality of decision makers is so limited by the human brain and organizational culture, decisions are rarely, if ever, optimal. If not optimal, then, what are they? Simon answered this question by calling organizational decisions "satisfying" decisions, that is, they satisfy the makers of decisions who suffice enough for the organizations to get satisfied (Simon, 2004: 89). This was a radical assertion in its day, when chief executive officers were assumed to be omniscient and infallible as long as the organizations they headed were still managing to lurch along. Simon was suggesting that even if the organization thrived, it would thrive infinitely more if the rational capacities of its decision makers were not so limited. Thus, individual decision makers and

\footnotetext{
i An alternative position on rationality (which includes both bounded rationality (Simons and Hawkins, 1949), as well as the affective and valuebased arguments of Weber) can be found in the critique of Etzioni (1988), who reframes thought on decision-making to argue for a reversal of the position put forward by Weber. Etzioni illustrates how purposive/instrumental reasoning is subordinated by normative considerations (ideas on how people 'ought' to behave) and affective considerations (as a support system for the development of human relationships) and March, James, and Herbert Simon (1993) which the researcher taken the latter as a reference for this study.
}

organizational decisions are less than rational. Therefore, this kind of model describes the concept, as individual decision makers have a minimally acceptable set of criteria (specified or unspecified) that they are looking for when seeking to solve a particular problem. People rarely optimize when they make decisions, instead, they satisfy. The decision makers must study all available alternatives to determine which ones are the most efficient or most likely to achieve the desired results. The incremental model by Lindblom (Lindblom, 1959: 79-88) begins with introducing a set of successive comparisons which he calls "branch method". He describes the incremental, pluralist policy analysis method that is in contrast to a rational-comprehensive method or "root method" which first clarifies values and the desired ends, and then finds the most appropriate means to the desired ends by taking into consideration all the relevant information. Thus, the test of good policy is to find the most appropriate means to the desired ends. The analysis is comprehensive, because every important factor is suppose to be taken into account. As a consequence, the policy analysts rely heavily on the theory. Linblom asserts that this is the ideal root method because of the bounded rationality of men, economics, politics and time constrainsts, which are not used in making the policy decisions. Moreover, the political systems of the democratic regimes encourage a step-by-step, incremental change process each time there are small variations from the status quo (Lindblom, 1959: 399). On the other hand, the selection of means and ends are closely intertwined. Since the means and ends are not distinct, the means-end analysis is not fruitful. Branch method users assume that the test of good policy is the agreement on the policy itself instead of agreeing on the most appropriate means. Thus, administrators first decide on the policy and then clarify the objectives. In this method, there is a systematic neglect of important values, potential policies, and possible policy outcomes for the sake of reducing the amount of information down to humanly manageable limits. Also, a succession of comparisons greatly reduces or eliminates the reliance of theory. In conclusion, Lindblom argues that in spite of all the claims to the contrary, nearly all policy decisions are made by the branch method. This is because the branch method is the only method which can deal with complex problems given the bounded rationality of men. He argues that the incremental model is also compatible with democratic political systems with its limitation of radical change and the resulting chaos. He argues that the systematical solving by the pluralist nature of the political system will assign "watchdogs" for nearly all interests. The Cohen, March and Olsen's "garbage-can model of organizational choice" (Cohen, 1972: 1-25) deals with the problem of organizational survival, as organizations deal with complex, intractable and wicked problems - problems with only temporary and imperfect solutions (Marmon and Mayer, 1986) - that cut across agencies vertically and 


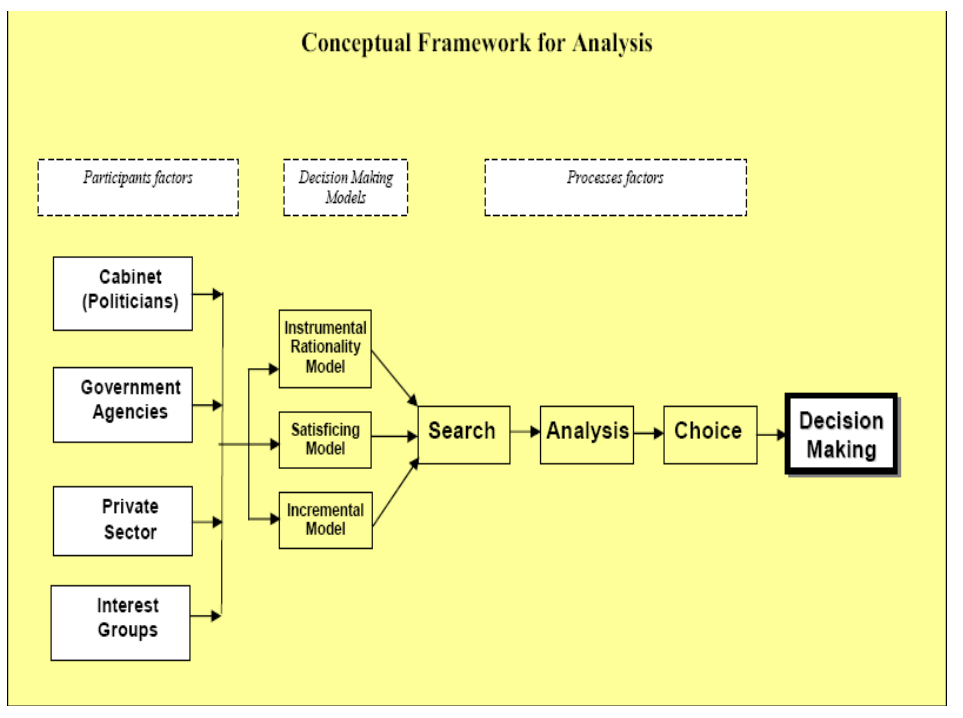

a
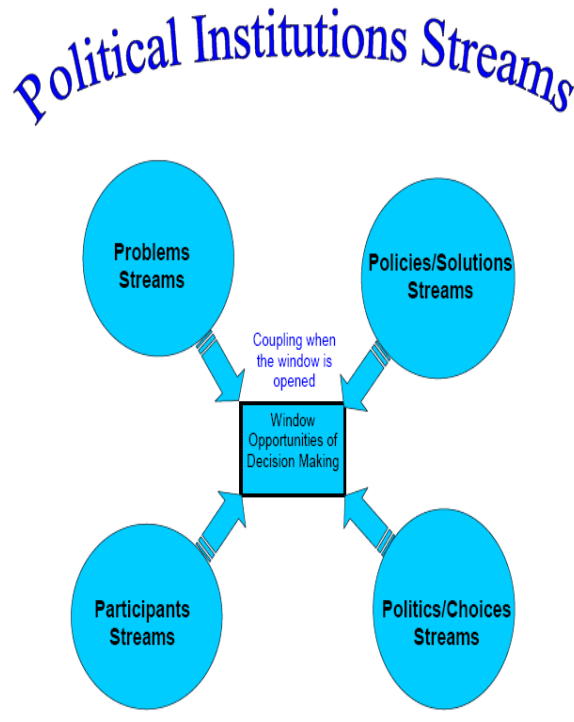

b

Figure 1. (a) Framework 1: Organizational decision-making models. (b) Framework 2: The Garbage-can model in political institutions according to Kingdon's theory.

horizontally (Brown and Brudney, 2001: 33) within unpredictable political, economic and social environments. The model questions the assumption of coherent, rational and intentional structures of organizational decisions. The authors of this model argue that, contrary to conventional wisdom, organizational goals are not consistent and welldefined, instead the processes to achieve these goals are not well understood by the organizational members. Finally, participation in organizational decision making is not systematic, to say the least. Most importantly, different components of the decision making processproblems, solutions and choices, do not necessarily follow each other in a linear fashion (such as, defining a problem seeking alternative solutions for it, choosing one solution over the others depending on its merits and implemention of that solution), but rather they follow a chaotic decision-making process in which solutions and problems are dumped into "garbage-cans" by organizational participants, and then are matched/coupled under suitable conditions. In a nutshell, organizations are defined as "organized anarchies", that is, a "collection of choices looking for problems and issues, feelings looking for decision situations in which they might be aired, solutions looking for issues to which they might be the answer, and decision makers looking for work" (Cohen et al., 1992).

\section{CONCEPTUAL FRAMEWORK FOR ANALYSIS}

The analytical framework for this study begins by elaborating the ideas in the existing decision-making theories and decision-making process models seen as central to an understanding of the government decisionmaking process on the policy level towards Thai SOEs. The literature review provides the researcher some insight about the variables to consider the dynamics of the decision-making process status, including the way to conceptualize the various players involved in an organizational decision-making process. Moreover, the researcher after reviewing the literature, saw that the evidence indicated only the single model, and cannot be the adequate framework. The researcher chooses a group of decision-making models, including Max Weber's Instrumental Rationality Model, Herbert A. Simon's Satisfying Model and Lindblom's Incremental Model for guiding the creation of the analytical framework which will use the framework in comparing the three steps of the decision-making processes (search, analysis and choice process) proposed by Harold et al. (1997: 194-213) for this study. In addition, the researcher alters the garbage can model, a model developed by March et al. (1979) to understand the government decision-making process, particularly the stage of agenda setting or search of problems stages and alternative generations or choice stages. The researcher conceived the decision-making process model known as "the Kingdon's Theory", whereas "the window of opportunity" occurred from the coupling of the streams of problems, policies, politics and participants, for guiding the creation of the analytical framework and for studying the government decision-making process on the policy level towards Thai SOEs as shown in Figure 1. 


\section{CASE STUDIES}

This study is a qualitative research, designed by using the caseoriented study. The unit of analysis is derived from the research questions:

(1) In the context of political structures and institutions surrounding the government decision-making process on the policy level towards state owned enterprises, which specific groups or individuals of the participants' factors are the major players in the government decision-making process?

(2) What process factors lead to or influence the government decision-making process on the policy level towards state owned enterprises?

(3) Under what conditions did the opening affected the window of opportunities which come from the coupling of the four streams of problems, policies, politics and participants?

(4) The government decision-making process on the policy level towards state owned enterprises has been done under which decision-making models in the 4 models?

The collection and analysis of data for this study relied on documentary and interview sources, including the decision makers and high-ranking officials, members of related government agencies and the two selected cases of state owned enterprises, involved in the decision-making process. The purposive and snowball samplings are used as efficient procedures and techniques for getting data to find the key informants relevant to various aspects of the government decision-making process on the policy level towards SOEs. The two selected cases provided an excellent opportunity to test the framework's ability to interpret the actions of the decision-making process participants. The researcher gathered data from various kinds of documents, which ensured that he had a good understanding of the background and events surrounding the decision-making process that are highlighted and remarked in the decision-making process. Among others, the news and articles, gathered from various Thai and English newspapaers in the period of time that the decision-making process took place, provided the researcher good information to ask and discuss with the informants. Besides, careful attention in the usage of multiple sources of data and the triangulation method gave the researcher the required confidence in getting the most effective and in-depth information for analysis. By using the qualitative technique, such as the inductive analysis with data reduction and data display, drawing conclusions, as well as interpreting, modifying, extending and refining the result of the study, was done during the whole process of this study. The researcher is confident that by this way of collecting and analyzing data, the findings will be useful in terms of ensuring creditability, dependability, and transferability.

However, there are some limitations in using the qualitative case study method which needed to be acknowledged. The limitations needed to be clarified here is the external validity. The results from the case study were difficult to generalize a larger population due to the specification of time and space of these two selected cases studies. Besides, the researcher faced the obstacles in contacting the high-ranking officials and high-profile politicians who are the key persons of these two selected case studies, as they had already retired or were barred from being involved in politics. Also, there was a time constraint limitation during the study.

This study is designed by using the case-oriented study as an indepth study on the dynamics of government decision-making process on the policy level towards two SOEs under the jurisdiction of the Ministry of Transport and Communications, Thai Maritime Navigation Company Limited (TMN), and the Airports of Thailand Public Company Limited (AOT). The background, characteristics and detailed features of each SOE are presented at the appendix.

\section{ANALYSIS OF THE RESEARCH FINDINGS}

This study follows an analytical framework that has been developed from various decision-making models. The conclusion of the findings can be summarized into four points:

(1) The government decision-making process on the policy level towards Thai SOEs relates to the country's economic development and political stability. The government's policy toward SOEs will create economic opportunities and multiple competing stakeholders among the various participants groups by creating business competition through the bidding and approaching for government contracts. These economical transactions highly affect government policy implementation.

(2) The government policies on the SOE privatization are part of the national economic and social development plan, which began in 1987. The policies were inconsistent and kept changing due to the national political and economic instability and the influence of the related participants groups who were having advantages from SOE privatization.

(3) The government decision-making process on the policy level towards Thai SOEs relates to many problems and many policies which lead to the conflicts of interest of various interest groups both inside and outside the government. Therefore, the context of the government decision-making process is complex and dynamic. These participant groups, therefore, try to push the policies that benefit them by using various strategies to influence the final decision.

(4) The study of government decision-making process on the policy level towards Thai SOEs is essential because this study focuses on the decision-making process that has resulted from the Cabinet's resolutions to the policy implementation process. Therefore, the successes or failures of the decision making process were critical for the successes or failures of the following stages, policy implementation process. This study, therefore, will help to understand the roles of the individuals or groups and the interaction among them in the decision-making process and examine who has the most potential influence on the decision-making process. Moreover, this study aims at examining those individuals or groups participating in the government decision-making process and their roles in making decisions, why those in and around the government pay more attention to some subjects than to others, and why under a particular circumstance, some decisions are made but some are not. This study, also, focuses on the influence or connection of various competing stakeholders. Ultimately, a better understanding of the government decision-making process may help ensure the better understanding of the changes occurring in government policies.

The results of the findings have been achieved from the analytical framework, designed to answer the research 
questions, "How did the participant and process factors, consisting of the agenda setting process, search and analysis process and choices process, in the government decision-making process on the policy level towards state owned enterprises, caused and affected the relationships or influenced the decision-making process on the policy level towards state owned enterprises?" and "Under what conditions and to what extent do the decisionmaking models help to clearly explain and precisely forecast the government decision-making process on the policy level towards state owned enterprises?" To answer these research questions more clearly, this study separates them into the following analysis and findings.

\section{Participant factors: Explanation of the political structures and institutions surrounding the government decision-making process on the policy level towards state owned enterprises}

For the first case study, that is, the Thai Maritime Navigation Company Limited in the matter of entering into a joint venture agreement with 23 shipowner companies to advance the process of the TMN Privatization and National Shipping Line Establishment Policy, the study found that there were a number of groups playing in the government decision-making process. However, they can be categorized into four groups: politicians, businesses, bureaucrats and interest groups. Among these four groups, there were 16 core groups prominent in influencing the agenda setting in the matter of entering into a joint venture agreement with 23 shipowner companies to advance the process of the TMN Privatization and National Shipping Line Establishment Policy. These groups included the politicians group (2 polititcians, Mr. Sanan Kachornprasart and M.L. Chengchan Kampoo, who came into power through appointment as the Minister of Transport by coup d' etat leaders; and 5 politicians, Mr. Anek Tabsuwan and Mr. Padermchai Sasomsap from the Democrat Party, Mr. Suwat Lipataphanlop from the Chart Pattana Party, Mr. Pinij Jarusombat from the New Aspiration Party, and Mr. Poomtham Vejayachai from the Thai Rak Thai Party, who came into power by election and taking the political post by being appointed as MOTC Minister), the groups of bureaucrats (MOTC, Marine Department, Harbour Department), Office of Maritime Promotion Committee (OMPC), Board of Investment (BOI), the group of the business sector (Unithai Co., Ltd., United Shipping Co., Ltd.), foreign ship-owner companies (COSCO and Llloyd Triestino), TSA' members (23 Thai ship-owner companies), and other interest groups (TMN's management and employees, academic group, media and the general public).

For the second case study, that is, the Airports of Thailand Public Company Limited on the Suvarnabhumi Airport Construction Policy, the study found that there were a number of groups playing in the government decision-making process. However, they can be categorized into four groups: politicians, businesses, bureaucrats and interest groups. Among these four groups, the 16 core groups were prominent in influencing the agenda setting on the Suvarnabhumi Airport Construction Policy. These groups included politicians [4 Prime Ministers - Field Marshal Sarit Thanarat, Field Marshal Thanom Kittikachon, General Prem Tinsulanond and Mr. Anand Panyarachun, and 6 MOTC Ministers and Deputy Ministers - Major General Pong Phunnagan, Air Chief Marshal Thavee Jullasap, Air Admiral Tinnakorn Phankravee, Mr. Samak Sunthornvej, M.L. Chengchan Kampoo and Mr. Nukul Prachobmoa, who came into power by coup d' etat, and 4 Prime Ministers who came into power by election - General Chatichai Choonhavan (PM during 4 August, 1988 to 23 February, 1991) from the Pattana Party, Mr. Banharn Silpa-archa (PM during 13 July 1995 to 25 November 1996) from the Chart Thai Party, Mr. Chuan Leekpai (PM during 23 September, 1992 to 13 July, 1995) from the Democrat Party and General Chavalit Yongchaiyudh (PM during 25 November 1996 to 9 November 1997) from the New Aspiration Party, Police Lt. Col. Thaksin Shinawatra from the Thai Rak Thai (Thais love Thai) Party, and 9 MOTC Ministers and Deputy Ministers who came into power by election Montri Pongpanich from the Kijsangkom Party, Mr. Chomphol Silpa-archa from the Chart Thai Party, Colonel Winai Somphong, Mr. Wichit Surapongchai and Mr. Suthep Theuksuban from the Democrats Party, Mr. Wan Muhammad Nor Matha, Mr. Suwat Lipataphanlop and Mr. Somsak Thepsutin from the New Aspiration Party and Mr. Suriya Jungrungruengkij from the Thai Rak Thai Party]; groups of bureaucrats [MOTC, Civil Aviation Department, Airport Authority of Thailand (AAT), National Economic and Social Development Board (NESDB), State Owned Enterprises Policy Office, Finance Ministry], the business sector groups including general engineering consultant and construction group [namely: the ItalThai Group and Nortrop Co., TAMS (Tippetts Appett McCarthy Stratton), NACO (Netherlands Airport Consultant), Louis Berger International, MJTA, $\mathrm{PCl}$ or PMC Project Management Consultant], and the group of other interest groups [Bangkok International Airport (Don Mueang Airport), Airports Authority of Thailand (AAT), Airports of Thailand Public Company Limited (AOT), New Bangkok International Airport Company Limited (NBIA), AOT's Management and Employees, Academics group, media and the general public].

The results from both case studies, found in the government policies towards TMN and AOT, showed that when comparing the four groups of participants involved in the government decision-making process on the policy level towards SOEs, the politicians group was the most important participant in the government decision-making process, followed by the business group, the bureaucrat groups, and other interest groups, respectively. However, 
Table 1. The era of four periods.

\begin{tabular}{|c|c|c|c|}
\hline $1^{\text {st }}$ Era (1977-1978) & $2^{\text {nd }}$ Era (1979-1987) & $3^{\text {rd }}$ Era $(1990-2000)$ & $4^{\text {th }}$ Era (2001-2007) \\
\hline $\begin{array}{l}\text { The JVs with the private } \\
\text { sector policy in the } 1^{\text {st }} \text { era was } \\
\text { in the semi-democratic regime } \\
\text { ruled by a military dictatorship. }\end{array}$ & $\begin{array}{l}\text { The } 2^{\text {nd }} \text { era was still in the } \\
\text { semi-democratic regime } \\
\text { overshadowed by the military. }\end{array}$ & $\begin{array}{l}\text { The political system in the } 3^{\text {rd }} \text { era } \\
\text { transformed from a semi-democratic } \\
\text { to a more democratic regime loosely } \\
\text { based on a party system. }\end{array}$ & $\begin{array}{l}\text { The TMN } \\
\text { Privatization Policy is } \\
\text { achieved. }\end{array}$ \\
\hline $\begin{array}{l}\text { The Cabinet members were } \\
\text { appointed by the military } \\
\text { leader. }\end{array}$ & $\begin{array}{l}\text { The government led the } \\
\text { economics policy under the } \\
4^{\text {th }} \text { National Economic and } \\
\text { Social Development Plan. }\end{array}$ & $\begin{array}{l}\text { There were massive changes in the } \\
3^{\text {rd }} \text { Era due to the change in } \\
\text { government and cabinet members. }\end{array}$ & $\begin{array}{l}\text { The Merchant } \\
\text { Maritime Master Plan } \\
\text { B.E. 2542-2549 ( } 1999 \\
\text { - 2006) by MOT. } \\
\text { TMN Business Plan. }\end{array}$ \\
\hline $\begin{array}{l}\text { The decision-making power on } \\
\text { SOEs was done by military } \\
\text { leaders, and done by the } \\
\text { ministry that oversaw those } \\
\text { SOEs. }\end{array}$ & $\begin{array}{l}\text { This era is known as the } \\
\text { "Technocrats" or Bureaucrats" } \\
\text { era. } \\
\text { SOEs also proposed their } \\
\text { own business development } \\
\text { plan in order to keep their } \\
\text { organization's survival. }\end{array}$ & $\begin{array}{l}\text { Every change in the government or } \\
\text { Cabinets, the Minister overseeing the } \\
\text { SOEs also changed. } \\
\text { The Ministry still played the major role } \\
\text { in moving the TMN Privatization } \\
\text { Policy forward. }\end{array}$ & $\begin{array}{l}\text { TSA initiative to have } \\
\text { JVs with } 23 \text { Thai } \\
\text { shipowner } \\
\text { companies. }\end{array}$ \\
\hline
\end{tabular}

when comparing individuals, agencies, or groups within each group, the study found that:

(1) Within the politicians group, the leader of the cabinet or government, particularly the Prime Minister, was the most important key player, while the Minister or the Deputy Minister of the MOTC was ranked as the second key player, respectively. The third ranking of the key players was the Minister or Deputy Minister of the related ministry, such as: Finance, Industry and Interior Ministries.

(2) Within the businesses group, for the first case study, Unithai Co. Ltd. (United Shipping Co., Ltd.) and TSA members (23 Thai ship-owner companies) occupied the first and second rank of the key players, respectively, and for the second case study, the ItalThai Group and Nortrop Co. occupied the first and second ranks of the key players in the beginning period, while MJTA and $\mathrm{PCl}$ or PMC Project Management Consultant occupied the first and second ranks of the key players in the latter period.

(3) Within the bureaucrat group, the MOTC, Marine Department (Harbour Department) and Office of the Maritime Promotion Committee (OMPC) occupied the first and second ranks of the key players, respectively in the first case study, while the MOTC, Civil Aviation Department and the National Economic and Social Development Board (NESDB) occupied the first, second and third ranks of the key players, respectively in the second case study. However, for the second case study, that is, the Airports of Thailand Public Company Limited on the Suvarnabhumi Airport Construction Policy, the results found that politics planned to take control of the project between these two government agencies (MOTC and NESDB).
(4) Within the interest groups, the study found that in these two case studies, the academic groups and the media were concurrently important in terms of expressing and assimilating their studies, analysis and opinions regarding the possibility of the corruption and conflict of interest on large infrastructure projects; such as, the Suvarnabhumi Airport's construction and the National Shipping Line Establishment. These expressions, more or less, caused delay in the government decision-making process towards these two SOEs and policy changing, while the other interest groups, such as the group of management and employees of the two SOEs or other associations that played a less important role through the political structures and institutions relating to the government decision-making process on the policy level.

The findings of the first case study suggested that the political structures and institutions relating to the government decision-making process on the policy level towards the Thai Maritime Navigation Company Limited in the matter of entering into the joint venture agreement with 23 shipowner companies to advance the process of the TMN Privatization and National Shipping Line Establishment Policy that started in 1977 that can be classified as the era of four periods. The four eras are displayed in Table 1.

The findings of the second case study suggested that the political structures and institutions relating to the government decision-making process on the policy level towards the Airports of Thailand Public Company Limited on the Suvarnabhumi Airport Construction Policy can be classified as the era of five periods. The five eras are displayed in Table 2.

Therefore, the historical approach analysis showed that 
Table 2. The era of five periods.

\begin{tabular}{|c|c|c|c|c|}
\hline $1^{\text {st }}$ Era $(1959-1963)$ & $2^{\text {nd }} \operatorname{Era~}(1963-1978)$ & $3^{\text {rd }}$ Era (1978-1987) & $4^{\text {th }}$ Era (1988-1995) & $5^{\text {th }} \operatorname{Era}(1997-2006)$ \\
\hline $\begin{array}{l}\text { The political structure } \\
\text { is centralized at the } \\
\text { "Leader". }\end{array}$ & $\begin{array}{l}\text { General Thanom } \\
\text { Kittikhajorn took over the } \\
\text { "Leader" power and } \\
\text { continued the new } \\
\text { international airport } \\
\text { project. }\end{array}$ & $\begin{array}{l}\text { The political structure of the } \\
\text { government decision-making } \\
\text { process on the policy level towards } \\
\text { SOEs was still in the hands of the } \\
\text { military government that came into } \\
\text { power by seizing power from other } \\
\text { military governments. }\end{array}$ & $\begin{array}{l}\text { The political structure of the } \\
\text { government decision-making } \\
\text { process on the policy level } \\
\text { towards SOEs was still in the } \\
\text { hands of the military } \\
\text { government that came into } \\
\text { power by seizing power from } \\
\text { other military governments. }\end{array}$ & $\begin{array}{l}\text { The democratic political } \\
\text { system led by an elected } \\
\text { government was the main } \\
\text { political structure. }\end{array}$ \\
\hline $\begin{array}{l}\text { SOEs policies were } \\
\text { the leader's concept } \\
\text { that would like to lead } \\
\text { the country towards } \\
\text { modernization. }\end{array}$ & $\begin{array}{l}\text { The authorized power to } \\
\text { make decisions was still } \\
\text { with the Cabinet led by } \\
\text { General Thanom. }\end{array}$ & $\begin{array}{l}\text { The military dictatorship was the } \\
\text { main political structure. } \\
\text { NESD Plan } 4 . \\
\text { SOEs legal and regulatory reforms. }\end{array}$ & $\begin{array}{l}\text { The military dictatorship was } \\
\text { the main political structure. } \\
\text { NESD Plan } 4 \text {. } \\
\text { SOEs legal and regulatory } \\
\text { reforms. }\end{array}$ & $\begin{array}{l}\text { There were } 4 \text { governments } \\
\text { that came from } 3 \text { political } \\
\text { parties; namely, New Hope } \\
\text { Party, Democrat Party, and } \\
\text { Thai Rak Thai Party, took } \\
\text { turns to govern the country. }\end{array}$ \\
\hline $\begin{array}{l}\text { "Technocrats" from } \\
\text { NESDB oversaw the } \\
\text { new international } \\
\text { airport construction } \\
\text { project. }\end{array}$ & $\begin{array}{l}\text { NESDB had a greater role } \\
\text { and more participation in } \\
\text { the decision-making } \\
\text { process in controlling the } \\
\text { New International Airport's } \\
\text { construction. }\end{array}$ & $\begin{array}{l}\text { Controlled and led by the } \\
\text { "Technocrats. } \\
\text { Policy of privatizing the non- } \\
\text { performing SOEs. }\end{array}$ & $\begin{array}{l}\text { Policy of privatizing the non- } \\
\text { performing SOEs. }\end{array}$ & $\begin{array}{l}\text { The announcement of the } \\
\text { PM's Regulations regarding } \\
\text { the } 2^{\text {nd }} \text { Bangkok } \\
\text { International Airport, B.E. } \\
2545 \text { (2002). }\end{array}$ \\
\hline
\end{tabular}

in this era, the government decision-making process on the policy level towards SOEs, TMN and AOT, on the Thai Maritime Navigation Company Limited in the matter of entering into a joint venture agreement with 23 shipowner companies was inconsistent in advancing the process of the TMN Privatization and National Shipping Line Establishment Policy and the Airports of Thailand Public Company Limited on the Suvarnabhumi Airport Construction Policy. The inconsistency of the state policy can be described to highlight the political dynamics of SOEs policy decisions. All the policy decisions, regarding these 2 projects, were taken at a slow and moderate pace reflecting the government's incapacity to reorient the implementation process to suit its own sense of priorities and interpretation of what would be best for the country and to open the opportunity window to fraud and corruption in being involved or getting into the construction bidding process. Frequent turnovers were seen, if the minister reflected the weakness and inability of the state policy implementation mechanism.

The findings of this study strongly suggest that the government decision-making process on the policy level towards SOEs is largely a function of each participant group. The function can be described in terms of who participates and what is their ability to frame the issues and take advantage of the opportunities when they happen after the government had made a decision. The government decision-making process, therefore, encompasses a variety of actitivies, trends and policy entrepreneurs. Those participants are engaged in a heterogeneous agenda setting process. They are essential to the success or failure of the decision-making process on the policy level and alternative specifications of the new policies. The characteristic of interaction of these participants can be seen as the supporting triangulated interactions, that is, the vested interest is worked around by the three groups. The business group sought the rent by creating new incentives and exchanging them with the politicians and bureaucrats. The politician, who acts as the Prime Minister, Minister or Deputy Minister overseeing the SOEs, serves and is served by the businessmen. Then, the businessmen pays to the bureaucrat, while the group of bureaucrats transmits whatever is speeding up or hanging on the issue to the politicians. The interest groups, such as academics, media, management and employee of the 
SOEs are outside of these triangulated interactions.

\section{Process factors (problems, solutions and choices): Explanation of the political structures and institutions surrounding the government decision- making process on the policy level towards state owned enterprises}

The deductions from the findings can be made here. The government decision-making process on the policy level towards SOEs has been developed through the interaction of three process factors: search, analysis and choice. The government decision-making rarely resulted from a linear process, rather, they come about through a process of iterative interactions among three streams of activities (defining the problem, suggesting solutions and obtaining political consensus). In the case of the Thai Maritime Navigation Company Limited in the matter of entering into a joint venture agreement with 23 shipowner companies to advance the process of the TMN Privatization and National Shipping Line Establishment Policy, the study found that the choice that was proposed by MOTC or selected by the MOTC Minister to the Cabinet was the process factor that led to or influenced the government decision-making process on the policy level towards TMN, while in the case of the Suvarnabhumi Airport Construction Policy, the study found that in a certain period of time in some eras, the three process factors (search, analysis and choice) sometimes occurred consecutively and in a certain period of time in another era, they came about through a process of iterative interactions among the three streams of activities. However, in a certain period of time, the findings indicated that only the choice process (such as, the Cabinet) had made a decision on cancelling the new Bangkok International Airport project at Nong Ngu Hao and decided to go on with the Don Mueang Airport renovation and expansion plan. However, the choice process happened without following the search and solution processes.

\section{Governmental decision making: Window of opportunities and coupling the streams}

The deductions from the findings can be made here. The government decision-making on the policy level towards SOEs is the process that has developed through the interaction of the three streams of problems, policies and politics. The factors that have affected the three streams are the government turnover and the change in the Minister and Deputy Minister of MOTC who oversee these two SOEs (TMN and AOT), as well as the recognition and definition of the pressure from various interest groups and the competing ideas and proposal of the policy entrepreneurs. The change in one of these factors also changed in the interest of the participants in the government decision-making process; hence, the change in the decision and policy changed on the policy level towards SOEs. Those changes rarely resulted from a linear process, rather, they came about through a process of iterative interactions among three streams of activities (defining the problem, suggesting solutions and obtaining political consensus). However, each activity sometimes could not come through, since it is characterized by a distinct set of problems, opportunities and contraints. The solution opportunity occurred when these streams of activities converged. During the flowing of three streams, the policy entrepreneurs play important roles in undertaking the decision making with the most potential to influence the final decision. However, among these policy entrepreneurs, only the government plays a central role in shaping the decision-making process on the policy level towards SOEs. The pressure or the feedback from other groups is not freely expressed enough to influence the agenda setting due to less power in the position and strategic roles. Moreover, the political dynamism and complexity surrounding the government decision-making process on the policy level towards SOEs have demonstrated that the government is unlikely to support any serious implementation of the National Shipping Line Establishment policy by privatizing TMN and the $2^{\text {nd }}$ Bangkok International Airport construction project. Thus, it places limits and constraints on the participants of some potential actors, while providing more power for other participants to exercise them close to the political control over the government decisionmaking process. In the face of these changes, the government decision-making process on the policy level towards SOEs becomes more concerned with accommodating the values of a participant group.

\section{The models of Government decision-making process on the policy level towards Thai State owned enterprises}

The finding from the two case studies found that in the semi-democratic regime, ruled by the military dictatorship of Field Marshal Sarit Thanarat and Field Marshal Thanom Kittikachon, the satisfying model can help to explain the processes of agenda setting. The study found that the "satisfying" decisions satisfy the makers of decisions who suffice enough for the organizations to get by, or uses a combined satisfaction (Nicholas, 2004: 89) to explain the processes of agenda setting done by both prime ministers. They have made decisions to satisfy themselves and due to the lack of monetary resources and more importantly, that of the sufficiency level of the technological capability, allowed little progress to be made in the following two decades. In the Sarit administration, the government approved to hire Litchfield, an airport engineering consultant company from the United 
States of America, to study the project and forecast of the Bangkok city plan for the next 30 years. The findings indicated that, in this era, the new international airport construction policy rarely resulted from a linear process of defining the problems, searching for the best solution and obtaining political consensus, instead it resulted from the national economics development towards modernization guidelines advised by the US consultants. In Thanom administration, the new international airport construction policy was also carried on further by the Nong Ngu Hao land expropriation who did purchasing for the new airport construction, while the engineering consultants and construction contract was still on hold due to the criticism and objection from many academics, media, general public and technocrats from the NESDB. In the case of the TMN Privatization and National Shipping Line Establishment policy, the findings indicated that the policy was initiated in the period of World War II (TMN was incorporated in 1940), in which there were huge demands of sea-going transportation, particularly munitions to be used for warfare. The decision maker who decided to establish TMN as a state-owned enterprise with $100 \%$ owned by the government with the registered capital of 6.2 million Baht was Field Marshal Plak Pibulsongkram.

Therefore, the findings indicated that the different factors opened the window of opportunity for each of the two case studies. The garbage-can model, with different components of the decision making process - problems, solutions and choices - do not necessarily follow each other in a linear fashion, but in a chaotic decision-making process in which solutions and problems are dumped into "garbage-cans" by organizational participants, and then are matched/coupled under suitable conditions (Cohen et al., 1972: 1-15). This helps to explain the process of agenda setting, while incremental models are more explanatory in the following stage. Once the policy is approved and announced by the Cabinet, the implementation process is initiated and placed on the public agenda. Consequently, policies are formulated, and the day-to-day operational decisions are made incrementally.

The researcher found that in the stage of the agenda setting, the garbage-can model, with different components of the decision making process (problems, solutions and choices) do not necessarily follow each other in a linear fashion, but rather in a chaotic decisionmaking process in which solutions and problems are dumped into "garbage-cans" by organizational participants, and then are matched/coupled under suitable conditions (Cohen et al., 1972: 1-15). This can help to explain the government decision-making processes very well. For example, the Cabinet's approval on improving and expanding the Bangkok International Airport (Don Mueang Airport) and putting the $2^{\text {nd }}$ international airport construction on hold, is approved by General Kriangsak's administration. This decision was made upon the proposal proposed by the MOTC Minister, Mr. Samak
Sunthornvej, in General Prem's admini-stration. The findings described that these policy entrepreneurs had been an enterprising public administrator who was waiting to use the media to get the political consensus for the given information. In the case of the TMN Privatization and National Shipping Line Establishment, the window of opportunity was opened when the 23 Thai shipowner companies, who were members of Thai Shipowners Association, proposed their JVs proposal, in a propotion of 70:30 according to MOTC. This time, the private sector had proposed to be the major shareholders of the JVs, which indicated that the private sector was eager to put their new investment, technologies and international shipping knowledge into these JVs. Therefore, with the willingness and readiness from the private sector, the window of opportunity was opened for privatization and would finally accelerate the National Shipping Line Establishment policy. Given the findings of this study, it is quite obvious that the conditions required the TMN privatization policy process, as described previously. According to the findings of this study, the business sector has played an active role in the policy making and implementation of the TMN privatization policy by both lobbying and bargaining with the government through the bureaucrats (such as, MOTC, Marine Department, BOI, NESDB and SEPO) to support and approve the proposal, while the government did not need to add any more investment funds. This is the decision that provided mutual benefits to all parties involved in the decision-making process on this issue.

\section{Conclusions}

This change of models from the garbage-can to the incremental model in the policy implementation processes is described by various cultural factors surrounding the government decision-making process on the policy level towards SOEs. The researcher found that one factor that makes the garbage-can and incremental models to be used to describe the government decisionmaking process on the policy level towards SOEs is the Thai administrative culture factor. Thai administrative culture is a popular topic in academic studies (Rangsan, 2003), while the Future Stabilization Policy Administration (Rangsan, 2003: 32) criticized the negative aspects of Thai administration, such as: the politics of expediency, high levels of centralization and administrative control, little delegation of authority, lack of detailed rational planning, slow inefficient decision making processes, and spending on non-budgetary funds including revolving funds, agency deposits, foreign loans, cash, bill transfer and other funds excluded from the budgetary process, by each SOE. The fund is easy to approve the budgeting that is set outside the annual government budget, particularly the use of retained earnings that do not need to be submitted to the State Treasury and loans from 
both domestic and overseas lenders. These budgets can be set and spent by each SOE without getting approval or consideration by the government. Rangsan argued that these investment plans, which are arranged and implemented by each SOE are not subject to the macroeconomics impact study and analysis, and will relate to the problem of the resources constraints and the crowding-out effect. Thak (1979) study of Thailand: The Politics of Despotic Paternalism, argued that the Thai political leaders (such as Field Marshal Sarit Thanarat) and the national development mentality have a dilemma nature. Historically, it has been a combination of Western-oriented characteristics (professional and rational mentality), indigeneous ones (status-oriented, mystical) and despotic paternalism (Professor Tamada, Cornell Southeast Asia Program Publications, 1989: 306). The paternalism relationship is important in expanding and retaining the political power and foundation. Therefore, powerful politicians are seeking the power base on the strength of economics and building up the connection with the potential interest groups in order to ensure their access to the resources to be used for maintaining these paternalism relationships. The agenda setting, and the government decision-making on policy levels and the large project management, is therefore done by powerful politicians through rent-seeking processes. The economics administration policy becomes the process of interest sharing and division for the despotic paternalism relationships (Rangsan, 2003: 99).

For the culture factor both facilitating and inhibiting the government decision-making process, the study's result shows that the culture factors that shape the government decision-making process on the policy levels towards SOEs in Thailand are: (1) The value attributed to strong leadership, (2) the culture of spending on non-budgetary funds, and (3) fascination with new public management which has a value attributed to a business-like management style. Some environmental factors that interact with these cultures factors are the market competition and value attributed to the SOEs reform and privatization movements, which lay emphasis on effectiveness and efficient management.

The first cultural factor that has a significant impact on the government decision-making process on the policy level towards SOEs is the value attributed to strong leadership. Strong leadership is perceived to be a crucial factor in the success or failure of the government decision-making process in various policies. The policy entrepreneurs need are internal and external organizational and political skills. The internal skills of organizing and motivating the related participants, providing a shared vision for the policy, and having knowledge and experience of implementing the project to success are attributed to strong policy leaders. The external skills of strong leaders are used for securing political support from organizational leaders or politicians (and thus securing funding), managing conflict with other departments and organizations, and persuading less technically competent stakeholders in the policy community, so that the outcome of the policy, either the TMN privatization and National Shipping Line Establish-ment and the New International Airport Construction, will not threaten their interest and status. However, strong leadership has its drawbacks. First, there is a risk of leaders slowing down the policy development due to their lack of knowledge of technical details, concepts and the latest technology of the particular policy. Secondly, too many dependent leaders causes a lack of institutionalization, which in turn causes delays in policy implementation when there is managerial or technical leadership change. Such changes are quite common, particularly in times of political and economic instability, and they contribute to the incremental nature and garbage-can nature of the decision making and planning processes.

The second cultural factor that affects the government decision-making process on the policy level towards SOEs in Thailand is the culture of spending on nonbudgetary funds. Besides, the SOEs operation must be under the government's policy and guidelines, but there are many policies that the government can easily give its approval if that policy is being implemented by using nonbudgetary funds. In the case of the TMN privatization, the JVs company was incorporated by using TMN's retained earnings since the share stakes that TMN took was only $30 \%$ of the total number of shares. These non-budgetary funds do not need to be sent to the national treasury. In the case of AOT, the findings found that AOT also used their retained earnings to hire the engineering consultants (TAMS) to do the survey and study the feasibility and plan for the new international airport construction at Nong Ngu Hao.

The third cultural factor is fascination with new public management which has a value attributed to a businesslike management style. Some environmental factors that interact with these culture factors are the market competition and value attributed to the SOEs reform and privatization movements that aim to lay emphasis on effectiveness and efficient management. However, this fascination, in contrast, can create good governance and transparency problem in the new public management. The public administration in the Thaksin Shinawatra administration was pooled in together by state mechanisms and used for the administration that emphasized the generation of the national economy. In many cases, this showed the problem of good governance and transparency in the Thaksin administration. One of the most visible aspects of Thaksin's administrative reforms was the restructuring of government departments and ministries, labeled the "big bang." It was hailed as a "historic breakthrough" and "the first major reorganization of ministries since King Chulalongkorn set up Thailand's modern system of departmental government in 1897." Plans had been studied for years to loosen perceived 
rigidities and inertia of the old system, but were not implemented until the Thaksin government (Martin, 2001). The Thaksin era also saw the opening of a number of government one-stop service centers to reduce red tape for anything from investment to utilities and ID-card processing. However, to understand the essence of the new public management in the government administration during the Thaksin administration reform, which is known as "reform movement in the 1990s", a set of core assumptions was introduced: money should be separated from politics, good and competent people should be able to participate in the political process, popular participation in politics and civil society should be boosted, and new institutions and new rules of the game are needed to control political actors and prevent abuses of power. Ironically, this mode of politics had many features in common with earlier kinds of political order in Thailand, which had centralized power in the hands of bureaucrats and military officers. The results from the reform made in the Thaksin administration is, in the other hand, centralization that was entirely around the office of an elected Prime Minister (McCargo and Ukrist, 2005: 14). The strength and power of the bureaucrats and military officers can be described by Riggs' work, which mentioned the new political structures after 1932 that the greatest institutional variance involved the kind of political system that existed when a coup took place. Sometimes they replaced a monarchy, repeating the Thai scenario. Much more often, however, coups merely replaced the leaders of one coup with another, which happened in Thailand quite often after 1932.

The study reveals therefore, that bureaucratic domination and rule by military officers is an inherently unstable form of government (Thak, 2005: 9). The strength of the bureaucrats was gradually destroyed in adverse relations with the country's economic development that emphasized the manufacturing producers, exporters, and international trading and monetary dependency. The opening up of the political order, combined with the economic successes of Thailand during the 1960s and 1970s, saw a new generation of Thai politicians starting to emerge with the entering into power of the new group that were not bureaucrats like civilian Prime Ministers (such as, Mr. Chuan Leekpai, Mr. Anand Panyarachun and Mr. Banharn Silpa-archa). These government leaders were not bureaucratic politicians who worked as a mediator to connect the business group that dominated Bangkok's nouveau riche entrepreneurial class and the bureaucrats. However, Thaksin's arrival in power was the ultimate outcome of the merger of money and politics that had characterized Thai politics in the 1980s and 1990s (McCargo and Ukrist, 2005: 4). The newly presented political policies and the CEO style was that practiced in leading business firms (CEO, 2003). It was used by the Thaksin administration and became the "loop hole" or "accountabilitiy vacuum" of the government's administration, which according to Lord Acton's (1887) saying "Power tends to corrupt, and absolute power corrupts absolutely." The crony culture and interest network created the disconnection of information and the government policy towards SOEs flows. Also, it led to new competition, adaptation and fighting over the new policy when the new Chairman or Board of each SOE was changed.

\section{Future and developing research: "The Government decision-making process on the policy level towards Thai State owned enterprises (SOEs) operating within Metropolitan Areas"}

The developing research analytical framework aims to interpret the dynamics of metropolitan areas or urban regions (Stone, 1989). The researcher would like to focus on the social forces and SOEs operation and administration within metropolitan environments. Having an assumption that the social forces and SOEs operation and administration are altering the patterns of local decision making from institutional to non-institutional and cross-institutional forms of governance, the metropolitan environments are unique places than they were decades before. In other words, the metropolitan have transformed into more complex environments of diversified power centers with cross-jurisdictional issues and demands (Wikstrom, 2002: 21-38). Therefore, the Government decision-making on policy level towards SOEs operating within metropolitan areas will be understood as a set of skills and tools that are framed around collaborative efforts designed to meet cross-jurisdictional and crossboundary needs of the public (Agranoff, 2003), private and non-governmental organizations (NGOs) (Linden, 2002). Drawing insights from the complexity theory (Richardson, 2005), the developed research aims to offer some ideas that may provide a useful interpretation of the SOEs operating within the metropolitan context from which we can understand metropolitan environments and the way in which decisions are made within these environments.

The research question explored in the developing research is "how are administrative, political and policy decisions formed in complex metropolitan environments?" This research question contains two different concepts. The first concept is the deeply traditional frame of reference that relies on the oft-touted principles of rational decision making. Long tradition in public administration and rational decision making theories are the bulwark of the field, and most approaches rely on the underlying principles and assumptions of the rationality in conducting and understanding decision making in public administration (Ferderickson and Smith, 2003). Under this concept, the emphasis of the quality of decisions is viewed as a result of a form of rationality that seeks to order policy decisions around the criterion of efficiency 


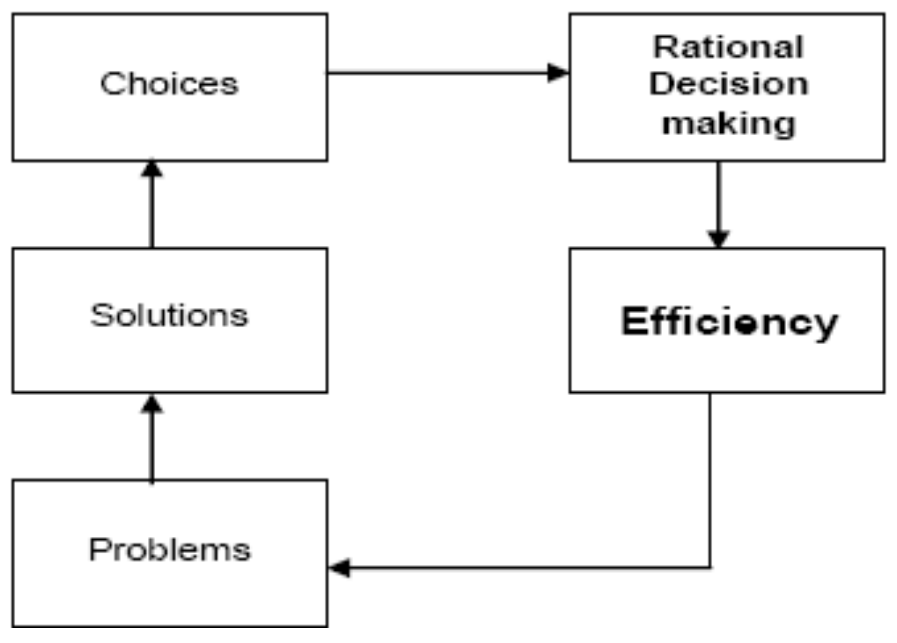

Figure 2. $1^{\text {st }}$ conceptual framework.

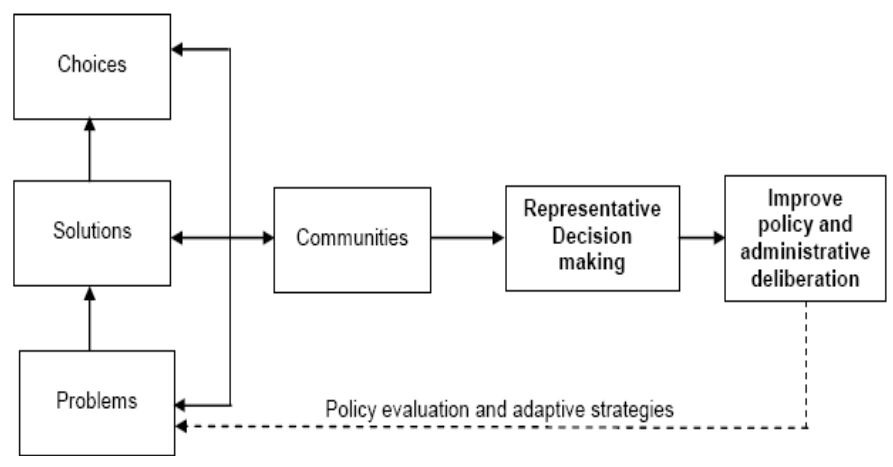

Figure 3. $2^{\text {nd }}$ Conceptual framework.

as shown in Figure 2.

The second concept places emphasis on a very different question of who is involved in the decision process. This approach to decision is representative of what is referred to as post-positivist (Fischer, 2000), in which there is a reliance on expanding the decision frames of reference to improve policy and administrative deliberation. The second concept that focus on expanding participation will lead to a more fully developed sense of understanding the problem at hand and a more fully committed response to the problem solution once meaningful involvement is achieved. This is shown in Figure 3.

The developing research aims to assess the use of rationality in the study of organizational behavior. As argued by Zey (1998: 88), organizational change and adaptation is best understood within the various contexts of organizations. Hence, the decision makers do not make decisions independent of their environments. The researcher believed that this understanding to examine organizations varies greatly from that outlined by rational choice theory and is being replaced by organizations "subjected to economic analysis in attempts to make them either accountable, productive or competitive."

The literature review will emphasize the broader, more inclusive nature of administrative and political decision making in public administration as referred to as the "logic of appropriateness" (Ferderickson and Smith, 2003), in which the decisions are based on shared understandings of the decision situation. The core value concepts will be derived from the work of Waldo (1952: 81-103), March and Olsen (1989) and March (1994), where it is understand that decision making is deeply contextual and is more attuned to the notions of social construction and sense making (Weick, 1995). However, it is to this mentality that the research focus is based on.

\section{REFERENCES}

Agranoff R (2003). Leveraging Networks: A Guide for Public Managers Working Across Organizations, IBM Endowment for the Business of Government, Arlington.

Brown MM, Brudney JL (2001). Achieving advanced electronic government services: An examination of obstacles and implications from an international perspective. Paper presented at the National Public Management Research Conference, Bloomington, IN p.33.

CEO governors mini-premiers, says PM: Can issue bonds, use management methods" (2003). Kellogg School of Management. 17 August

http://www.kellogg.northwestern.edu/news/hits/030817bp.htm.

Cohen MD, March JG, Olsen JP (1972). A garbage can model of organizational choice. Admin. Sci. Quart. 17:1-25.

Ferderickson HG, Smith KB (2003). The Public Administration Theory Primer. Westview Press, Boulder.

Fischer F (2000). Citizens, Experts and Environment: The Politics of Local Knowledge. Duke University Press, Durtham.

Harold FG, Julianne M, Jeanne BN (1997). "Organization Theory: The Pivotal Controversies" in Lane. pp.194-213.

Kingdon J (1995). Agemdas, Alternatives, and Public Policies. New York: Harper-Collins College Publishers p.85.

Lindblom CE (1959). The Science of muddling through. Public Admin. Rev. 19(2):79-88.

Linden RM (2002). Working Across Boundaries: Making Collaboration Work in Government and Nonprofit Organizations. Jossey-Bass, San Francisco.

Lord Acton (1887). Letter to Bishop Mandell Creighton.

March J (2004). A Primer on Decision Making: How Decisions Happen. The Free Press, New York.

March J, Olsen J (1989). Rediscovering Institutions. The Free Press, New York.

March J, Herbert S (1993). Organizations. $2^{\text {nd }}$ ed., Cambridge, Mass: Blackwell.

March J, Jihan O (1979 eds.). Ambiguity and Choice in Organizations. Bergen, Norway: Uniiversitesforlaget.

Marmon MH, Mayer RT (1986). Organisation Theory for Public Administration. Scott Foresman, Glenview.

Martin Painter (2001). Managerial Reform and Political Control, Department of Public and Social Administration, City University of Hong Kong, the Case of Thaksin and the Thai Bureaucracy, Research for this paper was conducted with the support of City University of Hong Kong Project Grant 720018.

McCargo D, Ukrist $P$ (2005). The Thaksinization of Thailand Copenhagen S, Denmark: NIAS Press p.14.

Michael MH, Richard TM (1986). Neo-Classical Theory: Organizations as Decision Sets. Organization Theory For Public Administration, Scott Foreman and Company, Glenview, Illinois London, England p.147.

Rangsan T (2003). The Process of Economic Policy Decision Making in Thailand. Kobfai Publishing Project p.99.

Richardson KA (2005). Managing Organizational Complexity: 
Philosophy, Theory, Application, Information Age Publishing, Greenwich, CT.

Saneh C (2006). Thai Politics and Constitutional Development. The Foundation for the Promotion of Social Sciences and Humanities Textbooks Project pp.261-263.

Simon (2004). Administrative Behavior, from Nicholas Henry, p. 89.

Simon HA (1955). A Behavioral Model of Rational Choice. Quart. J. Econ. 69(1):99-118.

Stone CN (1989). Regime Politics: Governing Atlanta, 1946-1986, University Press of Kansas, cited in Lawrence KS (1989). Thailand: The Politics of Despotic Paternalism (1989). Revised edition with new introduction, postscript, pictures, index,(Ithaca: Cornell Southeast Asia Program Publications 2007; co-published in Thailand by Silkworm Press, 2008). This book was awarded the first Ohira Prize (Japan) in 1985 and translated into Japanese by Professor Tamada of Kyoto University in 1989 p.306.
Thak C (1979). Thailand: The Politics of Despotic Paternalism. Thammasat University Press.

Waldo D (1952). Development of theory of democratic administration. Am. Pol. Sci. Rev. 46:81-103.

Weick KE (1995). Sensemaking in Organizations. Sage, Thousand Oak, CA.

Wikstrom N (2002). The city in the regional mosaic; In The Future of Local Government Administration, Frederickson, H.G. and Nalbandian, J., Eds., International City/County Management Association, Washington, DC pp.21-38.

Zey M (1998). Rational Choice Theory and Organizational Theory: A Critique, Sage, Thousand Osks, CA. 


\section{APPENDIX}

\section{Thai Maritime Navigation Company Limited (TMN)}

The Thai government established Thai Maritime Navigation Co. Ltd (TMN) in 1940 during the war in Europe between the Allies and the Axis powers. Since the war resulted in a higher demand for shipping in Asia, the Thai government decided to establish its own national shipping line. The government held $100 \%$ of the equity in the company, whose registered capital was originally 6.2 million Baht and was later increased in 1965 to $117,612,000$ Baht, and has remained at this level until now. During 1957 to 1977 , TMN's fleet totaled 16 vessels with a total capacity of 200,000 dead weight tonnes. The financial performance, in the first phase since incorporation, was profitable and thus went well. However, as time passed by, TMN's fleet became inefficient and offbooked, since there was no government policy on the fleet's rejuvenation plan and capital injection in new business expansion. Finally in 1986, TMN faced business losses and had to sell out all existing vessels and ended up with accumulated losses of 300 million Baht.

TMN has been carrying on its business operation without having its own vessels by chartering the dead weight tonnes and spaces from other shipowning companies to service its current customers. In the meantime, TMN has improved its business operation system, particularly, emphasizing on strategic marketing and accessing into more commercial marketing. Finally, TMN has successfully removed its losses and started to turnaround. In the meantime, TMN's management proposed a business proposal by acquiring more vessels for their operation, but the plan was rejected by the government since the government's policy at that time, was for no increase in investment in SOEs. Later in 1987, TMN reproposed its business plan for the government's consideration by privatizing and conducting joint ventures with private companies. The privatization plan was not achieved and was done at a slow and moderate pace, reflecting the government's incapacity to reorient the decision-making process to suit TMN's business proposals. The changes in politics and the frequent turnover in government during 1987 to 2000 caused the inconsistency of the government's polices towards TMN. The government turnovers caused the delay in consideration and approval, and finally the plan was on hold until October 30, 2001, when the Ministry of Transport and Communications submitted the TMN privatization plan to the Cabinet meeting for consideration. The plan was to allow Thai shipowner companies to purchase $49 \%$ of TMN's shares in order to increase the company's investment, and $51 \%$ of TMN's shares would be held by the government. Also, TMN would have the right on the port concession and could operate the port as part of their business. However, this plan was not achieved due to the political dynamics and complexities surrounding TMN and the national policy on establishing a national shipping line. In July 2005, during the term of the Thaksin Shinawatra government in which Mr. Phoomtham Vejayachai, Deputy Secretary-general of the Thai Rak Thai party, was the Deputy Minister of the Ministry of Transport and Communications, the Minister's policy towards TMN was given out to all concerned. The policy was to coordinate with the Thai Shipowners Association (TSA) to process the feasibility study on a joint venture with TMN for escalating the National Shipping Line Plan. Later in August, TSA submitted a letter to TMN to inform them that the TSA members, which consisted of 23 shipowner companiesii, had the intention of doing the joint venture with TMN as proposed by the government. In this regard, TMN's Board of Directors considered and approved the joint venture proposal with the proportion of giving TSA to hold $70 \%$ of the shares and TMN to hold $30 \%$. Furthermore, the JVs company was allowed to operate and provide services in the same way as TMN and takeover all rights that belonged to TMN for another 5 years. Later, TMN submitted the National Shipping Line Plan to the Cabinet meeting for consideration and approval. The plan consisted of the details of the portion of shareholding, the source of funds for JVs investment, the expenses and financial obligations occurring in the future in the amount of 200 million Baht, while TSA's contribution as a new investor in the JVs company was 466 million Baht. The funds were equally contributed by 23 shipowner companies. Then in November, the Cabinet issued the resolution on approving the JVs proposal projected by the Ministry of Transport and Communications and appointed 2 committees. The first committee was the working committee to work on the change of management regarding human resources in the matter of setting up a JV's company with 23 shipowner companies and another committee to study the transferring of transactions regarding the JV's company establishment. The JV's company between TMN and the 23 shipowner companies was incorporated on April 11, 2006.

\section{Airport of Thailand Public Company Limited (AOT)}

The new Bangkok International Airport or Suvarnabhumi Airport [the old name is Nong Ngu Hao (Cobra Swamp) Airport] is located in Racha Thewa, Bang Phli District,

\footnotetext{
The 23 shipowners companies including; (1) Ngow Hock Agency, (2)Jutha Marine Public Company Limited, (3) Precious Shipping Public Company Limited, (4) Sang Thai Navigation 1977 Co.,Ltd, (5) Nathalin Co., Ltd., (6) Harinsuit Transport Co.,Ltd., (7) C.\&P. COMPANY LIMITED, (8) Siam Paetra International Co., Ltd. , (9) Khunnathee Co., Ltd. (10) B.P.P. Supply Co.,Ltd. (11) Phurimas Navy Co., Ltd. (12) Tranns Ocean Supplies Co., Ltd., (13) Thavorn Marine Co., Ltd., (14) Y.C. Namsai Co., Ltd., (15) T.S.V. Supplies Co., Ltd., (16) N.T.L. Marine Co., Ltd., (17) Uni Oil Bulks Transport Co., Ltd., (18) United Tanker Co., Ltd., (19) V.C.C. Marine Services and Transport Co., Ltd. (20) Karnjana Marine Co., Ltd., (21) Asia Seatrans Co., Ltd., (22) Harin Panitch Co., Ltd., (23) TIPS CO., LTD.
} 
Samut Prakan Province. It was officially opened on September 28, 2006, and the airport inherited the airport code BKK from Don Mueang after the older airport ceased international flights and opened most domestic and international commercial flights. The government's policy set Suvarnabhumi Airport to be the main international airport of the country and aimed to make the airport to be the aviation hub of South East Asia. Suvarnabhumi Airport means "Golden Land". His Majesty, the King, graciously conferred the name of Suvarnabhumi Airport on September 29, 2000, and His Majesty, King Bhumibol Adulyadej, proceeded to preside over the foundation stone laying ceremony of the passenger terminal on January 19, 2002. The spelling of the official name of the airport was done according to the Sanskrit language "Suvarnabhumi" instead of following the Royal Instiitute's procedure, which would be spelt as "Suwannaphum". The 8,000 acre $\left(32 \mathrm{~km}^{2}\right)$ plot of land in Nong Ngu Hao, Samut Prakan Province occupied by the new airport was purchased in 1973 in the era of Field
Marshal Thanom Kittikachorn's government. The new airport construction project was carried on by several governments since then, but they never achieved success. After a series of ups and downs, the civil construction began once again in January 2002 during the government of Thaksin Shinawatra. The Thaksin government set the priority of the new airport construction project to be a national agenda and escalated and integrated the project with all related governement agencies. Finally, the symbolic first test were held on September 29, 2005, and Prime Minister Thaksin Shinawatra together with his cabinet members traveled from Don Mueang Airport to Suvarnabhumi Airport as the first group of passengers. Nevertheless, the airport was guaranteed by the International Civil Aviation Organization (ICAO) and the International Air Transport Association (IATA), who gave the status of operational readiness and certified that the airport had met all the safety and security standards to receive full certification. 